\title{
A GHASTLY RISING RATE OF PREVENTABLE PEDIATRIC BURNS: WE NEED TO ACT
}

\author{
Muhammad Rizwan Aslam, Taokeer Ahmed Rizvi, Muhammad Tariq Munawar, Asad Maqbool, Shahid Naqvi* \\ Combined Military Hospital, Kharian/National University of Medical Sciences (NUMS) Pakistan, *Combined Military Hospital, \\ Quetta/National University of Medical Sciences (NUMS) Pakistan
}

\begin{abstract}
Objective: To ascertain the increase in paediatric burn admissions. Find various causes of this trend and assess the morbidity and mortality in paediatric population, and suggest remedies.

Study Design: Cross sectional study.

Place and Duration of Study: This study was conducted at department of Burns \& Plastic Surgery, Army Burn Centre, Combined Military Hospital, Kharian, from Sep 2017 to Aug 2019.

Methodology: Total number of acute burn admissions under 12 years were recorded. Sub divided this group into 0-2 years and 2 to 12 years. We assessed epidemiology, sex, cause of burn, mode of admission, location of incident, type of first aid given, mortality, and compared results during two equal halves of this period. We used SPSS 20 for data analysis.

Results: A total of 504 (49.85\%) were pediatric acute burn admissions. Age range 25 days to 12 years (mean $5 \pm 1.2$ years). One hundred and fifty two infants/toddlers aged 0-2 years. Two hundred and seventy male and 234 females. Three hundred and sixteen direct admissions. There were $72.43 \%$ more pediatric burn admissions. Three hundred and eighty one scalds, 91 flame burns, 21 electric burns and 11 chemical burns. There was $11.94 \%$ improved survival among burn patients. Two temporal peaks, largest in summer from May to Jul and second in winters. The first peak in summers is unique in subcontinent. This is the time of summer vacations in schools when children are less well supervised.

Conclusion: There is a rising trend of preventable pediatric burns. A mass public awareness program is the need of the hour.
\end{abstract}

Keywords: First aid, Mortality, Pediatric burns, Prevention, Severity of burns, Survival.

This is an Open Access article distributed under the terms of the Creative Commons Attribution License (http://creativecommons.org/licenses/by/4.0), which permits unrestricted use, distribution, and reproduction in any medium, provided the original work is properly cited.

\section{INTRODUCTION}

Burns are the fifth most common cause of non-fatal childhood injuries ${ }^{1}$. Incidence of burn injuries is highest among children below 4 years of age ${ }^{2}$. Pediatric burns constitute almost half of overall burn admission load in our setup. There are various reasons for this staggering rate of pediatric burns ${ }^{3,4}$. Studies worldwide have demonstrated that the factors responsible range from children's impulsiveness, lack of awareness, higher activity levels due to natural curiosity, and total dependency on caregivers ${ }^{5}$. Several other factors, including poverty, overcrowding, lack of proper safety measures, lack of proper supervision, use of common areas for both cooking and sleeping, traditional habits of cooking over low stoves or in large pots (boiling milk), consuming

Correspondence: Dr Muhammad Rizwan Aslam, Army Burn Centre, Combined Military Hospital, Kharian Pakistan

Received: 13 May 2020; revised received: 21 Sep 2020; accepted: 30 Sep 2020 food while sitting on the floor, transferring hot liquids in open containers from one place to another, and sterilization of milk by boiling rather than pasteurization ${ }^{6,7}$ are to blame. In our rural and even in urban setting placement of young girls in household roles such as cooking and care of small children, easy access to chemicals, use of kerosene (paraffin) as a fuel source for non-electric domestic appliances and inadequate safety measures for liquefied petroleum gas and electricity are also cause of grave concern ${ }^{8}$.

Thermal injury in children is associated with a very high incidence of mortality and significant physical/psychological morbidity. All these injuries have the potential to result in devastating long-term effects in the form of severe scarring, permanent disfigurement and functional disability due to contractures and restricted range of motion of limbs. Pediatric burns may not only cause life-long disability, but also affect the 
mental health and quality of life of patients and their families, imposing a grave socioeconomic burden ${ }^{9,10}$.

There is a widely prevalent taboo or notion among majority general population in the IndoPak subcontinent that pouring water on burns will cause blisters and is prohibited, which as a matter of fact leads to much increased depth and severity of burns. This directly translates to severe post burn contractures, disabilities or fatalities $^{7}$. A huge number of loss of productive future work force results because of this misconception.

One of the reasons for this fallacy is lack of education and more reliance on quacks and faith healers. It is our impression that the root cause of this misconception lies in the era when population did not have access to clean water, and the main source was wells and ponds. Correction of this ill learned concept by our general population needs overall improvement in living standards and education of the masses.

Majority of these accidental serious thermal burns are preventable. The rising indulgence of adults in cell phones/tabs over social media is partly to be blamed. There is not a single dedicated burn care facility for pediatric population in Pakistan. Management of Pediatric burns is a very daunting task. It was our impression that the pediatric burns admission rate was significantly more than the last year.

It is also a point of concern that there is no laid down national action plan for burn prevention/ first aid. Public awareness/education is not getting its due share in print or electronic media. Lack of governmental resolve and ineffective imposition of existing legislation regarding building, fire/ gas/ electricity safety are also responsible for this rising trend of pediatric burns ${ }^{5}$.

\section{METHODOLOGY}

This is a "Cross sectional study" conducted at department of Burns \& Plastic Surgery, Army Burn Centre, Combined Military Hospital Kharian, from September 2017 to August 2019. Our department is a 20 bed burn care facility with 12
ICU beds, 8 stepdown beds and 20 convalescence beds outside the main building as part of a tertiary care facility. It has its own four operating theatres with three resuscitation bays having general anesthesia facility. It has its own CSSD. It receives patients from all over the country. We have split the time period of study into two equal halves i.e. Sep 17 to Aug 18 and Sep 18 to Aug 19 to ascertain the differences among various study parameters between these two years. Record of all acute burn admissions during study period was sifted through, all acute burns were collated and then record of pediatric burn patients was separated. Data sheet record was tabulated according to the study parameters and analyzed. We included all acutely burnt children aged 1 day to 12 years admitted to our tertiary care facility. Our sample size comprises of all acute pediatric burn admissions during this period. There was no gender bias. All readmissions for secondary procedures or old treated burns were excluded from the study.

Written permission was obtained from institutional research ethics committee.

In this study multivariate analyses were carried out to determine the pediatric burn incidence, etiology, TBSA \%, mode of admission, incidence among infant/toddlers vs children of 2-12 years, first-aid treatment methods, location of incident, parent/guardian knowledge of burns and the mortality rate in children.

A record of all acute burn admissions during the study period was created, out of these children were separated. Data was entered and analyzed using the Statistical Package for Social Sciences (SPSS), v 20.0 (IBM SPSS Statistics, Armonk, NY). Descriptive statistics were applied to find frequencies, percentages, means, and standard deviations. Quantitative variables, such as age and $\mathrm{TBSA} \%$, were expressed as means and standard deviations.

\section{RESULTS}

Total 1011 (441, 2017-18/570, 2018-19) patients with acute burn were admitted to our facility during the period of September 2017 to 
August 2019. Out of these 504 (185, 2017-18/319, 2018-19) $49.85 \%$ were children. Their age ranged from 25 days to 12 years (mean $5 \pm 1.2$ years). Out of these 504 children, 152 (59, 2017-18/93, 201819) $30.16 \%$ were infants/toddlers aged $0-2$ years. There were $270(53.57 \%)$ male and $234(46.43 \%)$ females, male to female ratio was 1.15:1. 316
There were $29.25 \%$ more over all admissions between 2017-18 and 2018-19. Whereas the total increase in pediatric patient admission was $72.43 \%$. There was $2.74 \%$ reduced number of infants and toddlers between $0-2$ years. There were $59.61 \%$ more males and $88.88 \%$ more females admitted in this total period. Standard Lund

Table-I: DATA of Cohat (Sep 2017 - Aug 2018).

\begin{tabular}{l|c|c|c|c|c|c|c}
\hline Months & $\begin{array}{c}\text { Total } \\
\text { Burns }\end{array}$ & $\begin{array}{c}\mathbf{0 - 1 2} \\
\text { years }\end{array}$ & $\begin{array}{c}\mathbf{0 - 2} \\
\text { years }\end{array}$ & Male & Female & Deaths & $\begin{array}{c}\text { Individual \% Total Body Surface } \\
\text { Area of Deaths }\end{array}$ \\
\hline Sep 17 & 18 & 6 & 2 & 3 & 3 & $1(16.67 \%)$ & $24 \%$ \\
\hline Oct 17 & 28 & 14 & 5 & 5 & 9 & $3(21.43 \%)$ & $40 \%, 35 \%, 60 \%$ \\
\hline Nov 17 & 16 & 6 & 5 & 5 & 1 & - & - \\
\hline Dec 17 & 37 & 19 & 9 & 11 & 8 & $7(36.84 \%)$ & $50,10,26,26,50,18,56 \%$ \\
\hline Jan 18 & 39 & 16 & 3 & 11 & 5 & $7(43.75 \%)$ & $40,40,40,75,35,55,15 \%$ \\
\hline Feb 18 & 31 & 15 & 5 & 10 & 5 & $1(6.66 \%)$ & $36 \%$ \\
\hline Mar 18 & 34 & 17 & 5 & 7 & 10 & $4(23.53 \%)$ & $40,80,35,50 \%$ \\
\hline Apr 18 & 41 & 20 & 11 & 15 & 5 & $4(20 \%)$ & $30,80,40,25$ \\
\hline May 18 & 63 & 27 & 1 & 14 & 13 & $10(37.04 \%)$ & $65,35,85,70,70,50,20,70,50,50 \%$ \\
\hline Jun 18 & 47 & 18 & 3 & 8 & 10 & $12(66.66 \%)$ & $25,70,20,50,60,80,55,75,50,95,15,25 \%$ \\
\hline Jul 18 & 36 & 15 & 8 & 8 & 7 & $6(40 \%)$ & $35,60,40,62,65,40$ \\
\hline Aug 18 & 33 & 12 & 2 & 7 & 5 & - & - \\
\hline total & 441 & 185 & 59 & 104 & 81 & $55(29.73 \%)$ & \\
\hline Tab-II & & & &
\end{tabular}

Table-II: DATA of Cohat (Sep 2018 - Aug 2019).

\begin{tabular}{l|c|c|c|c|c|c|c}
\hline Months & $\begin{array}{c}\text { Total } \\
\text { Burns }\end{array}$ & $\begin{array}{c}\mathbf{0 - 1 2} \\
\text { years }\end{array}$ & $\begin{array}{c}\mathbf{0 - 2} \\
\text { years }\end{array}$ & Male & Female & Deaths & $\begin{array}{c}\text { Individual \% Total Body Surface } \\
\text { Area of Deaths }\end{array}$ \\
\hline Sep 18 & 36 & 16 & 5 & 11 & 5 & $3(20 \%)$ & $50,50,60 \%$ \\
\hline Oct 18 & 42 & 19 & 7 & 8 & 11 & $1(5.26 \%)$ & $40 \%$ \\
\hline Nov 18 & 45 & 27 & 9 & 13 & 14 & $4(14.81 \%)$ & $35,35,35,25 \%$ \\
\hline Dec 18 & 45 & 29 & 16 & 11 & 18 & $3(10.34 \%)$ & $25,40,28 \%$ \\
\hline Jan 19 & 79 & 41 & 14 & 22 & 19 & $2(4.88 \%)$ & $45,60 \%$ \\
\hline Feb 19 & 47 & 26 & 13 & 14 & 12 & $5(19.23 \%)$ & $45,95,35,35,25 \%$ \\
\hline Mar 19 & 47 & 22 & 2 & 12 & 10 & $1(4.55 \%)$ & $40 \%$ \\
\hline Apr 19 & 45 & 17 & 2 & 10 & 7 & $5(29.41 \%)$ & $30,80,35,40,17 \%$ \\
\hline May 19 & 40 & 26 & 4 & 6 & 20 & $5(19.23 \%)$ & $55,20,35,35,25 \%$ \\
\hline Jun 19 & 53 & 30 & 6 & 19 & 11 & $3(10 \%)$ & $18,80,45 \%$ \\
\hline Jul 19 & 53 & 43 & 8 & 28 & 15 & $8(18.60 \%)$ & $55,35,50,36,25,30 \%$ \\
\hline Aug 19 & 39 & 23 & 7 & 12 & 11 & $3(13.04 \%)$ & $10,45,30 \%$ \\
\hline total & 570 & 319 & 93 & 166 & 153 & $43(13.48 \%)$ & \\
\hline
\end{tabular}

$(62.70 \%)$ patients were direct admissions whereas $188(37.30 \%)$ were indirect admissions which were initially treated at home, by quacks or other hospitals and most of the time brought due to complications/sepsis. All this data plus the mortality and their \% TBSA (total burnt surface area) are tabulated in table-I \& table-II. and Browder chart as appropriate for patient age were used for rapid assessment of total body surface area (TBSA) involved. The majority of mortality cases had serious burns with average TBSA $\%$ of $40 \%$ as is evident in (table-I \& II). Few cases with TBSA $\%$ ranging from $10 \%$ to $15 \%$ were all indirect admissions, admitted in critical state with severe sepsis in all and ARDS in 2 cases. The 
mortality rate among 441 children during first half of study was $26.05 \%$ vs $14.11 \%$ among 570 admissions in second half of the study period. There was a significant improvement of $11.94 \%$ in ring 2018-19 there is tangible reduction in the mortality rate.

The most common etiology was scalding $(381 / 504,75.60 \%)$, followed by flame $(91 / 504$,

Table-III: Occurrence of Pediatric burns / analysis of mortality between 2017-18 and 2018-19.

\begin{tabular}{l|c|c|c|c|c|c}
\hline & Total & $\mathbf{0 - 1 2}$ years & $\mathbf{0 - 2}$ years & Male & Female & Mortality \\
\hline $\begin{array}{c}\text { Sep 2017 - } \\
\text { Aug 2018 }\end{array}$ & 441 & $\begin{array}{c}185 \\
43.24 \% \text { of total } \\
\text { burns }\end{array}$ & $\begin{array}{c}51.89 \% \text { of total } \\
\text { children }\end{array}$ & 104 & 81 & $26.05 \%$ \\
\hline $\begin{array}{l}\text { Sep 2018 - } \\
\text { Aug 2019 }\end{array}$ & 570 & $\begin{array}{c}319 \\
55.96 \% \text { of total } \\
\text { burns }\end{array}$ & $\begin{array}{c}99.15 \% \text { of total } \\
\text { children }\end{array}$ & 166 & 153 & $14.11 \%$ \\
\hline Inference & $\begin{array}{c}29.25 \% \text { more } \\
\text { admissions }\end{array}$ & $\begin{array}{c}72.43 \% \text { more } \\
\text { admissions }\end{array}$ & $\begin{array}{c}2.74 \% \text { less } \\
\text { admissions }\end{array}$ & $\begin{array}{c}59.61 \% \\
\text { more boys }\end{array}$ & $\begin{array}{c}88.88 \% \\
\text { more girls }\end{array}$ & $\begin{array}{c}11.94 \% \text { improved } \\
\text { survival }\end{array}$ \\
\hline
\end{tabular}

overall survival rate among thesechildren in the second half (table-III).

The data was plotted on a chart (fig-1). It

Table-IV: Cause vs frequency of burn percentage.

\begin{tabular}{|c|c|c|}
\hline Type & Frequency & Cause \\
\hline Scalds & $381 / 75.60 \%$ & $\begin{array}{l}\text { Water } \\
\text { Milk } \\
\text { Curry } \\
\text { Tea } \\
\text { oil } \\
\end{array}$ \\
\hline $\begin{array}{l}\text { Flame / } \\
\text { contact } \\
\text { burns }\end{array}$ & $91 / 18.05 \%$ & $\begin{array}{l}\text { Gas explosion } \\
\text { Candles/ Lamps/ fire } \\
\text { Inflammable liquids } \\
\text { Contact with hot } \\
\text { surfaces (Heaters, stove, } \\
\text { cooking plates, Utensils) }\end{array}$ \\
\hline $\begin{array}{l}\text { Chemical } \\
\text { Burns }\end{array}$ & $11 / 2.18 \%$ & $\begin{array}{l}\text { 1. Common house hold } \\
\text { Acids (toilet cleaners, } \\
\text { sweep) } \\
\text { 2. Common house hold } \\
\text { Alkalis (Bleach) } \\
\text { 3. White } \\
\text { phosphorous/Sulphur }\end{array}$ \\
\hline $\begin{array}{l}\text { Electric } \\
\text { Burns }\end{array}$ & $21 / 4.17 \%$ & $\begin{array}{l}\text { 1. Household electricity } \\
\text { 2. High voltage } \\
\text { electricity from exposed } \\
\text { transmission line and } \\
\text { transformers placed on } \\
\text { ground }\end{array}$ \\
\hline
\end{tabular}

graphically shows the significant increase in the overall and children admissions during two halves of the study period. It also highlights that in spite of many more pediatric admissions du-
$18.05 \%)$, electricity $(21 / 504,4.17 \%)$, chemicals $(11 / 504,2.18 \%)$, (table-IV). As for temporal distribution, burn events occurred most frequently in July $(n=58,11.51 \%)$, followed by May $(n=53$, $10.54 \%)$ and Jun \& Dec ( $\mathrm{n}=48,9.54 \%)$, (table-I, II).

Regarding the first response of the care giver/attendant at the time of incident, $78 \%$ panicked, had no clue what to do and either removed clothes/applied household remedies or rushed to nearest doctor/hospital. Only $22 \%$ of the time the parent or attendants first response was to pour water or cold liquid on the burns, before any other measure.

In infants and very young, the commonest cause was immersion in boiled milk or water by slipping from hands of elder into the pot or immersion of a playing or standing toddler in the pot lying on the floor. It was also noted that among scalds the depth and severity of burns was worst with cooking Oil and milk (due to high fat contents of unskimmed milk). Other causes were boiling Curry, tea, gas explosions and fires.

Almost $90 \%$ of burns happened in the home and $10 \%$ occurred around homes, schools or other areas. Out of domestic accidents, $80 \%$ happened in kitchen, $15 \%$ in bathroom, bedrooms or hall ways and $5 \%$ in the vicinity of home ${ }^{11-13}$.

\section{DISCUSSION}

The occurence of pediatric burn in our study was almost $50 \%$, which is a staggering incidence. Dhopte $e t a l^{8}$ from Delhi India in their prospective 
epidemiological study have also shown 475 pediatric admissions in one year which is a large number for any centre. They have also inferred that scalds were the commonest cause closely followed by thermal flame/electric burns. They also showed two temporal peaks in 1st and 3rd season was spring. This was in contrast to our study where scalds were $76 \%$. About $90 \%$ burns occurred in the home and we had two peak injury seasons that is June/July (summer) and Dec/Jan (winter).

Table-V: Type of first aid given vs site of accident.

\begin{tabular}{|c|c|c|c|c|}
\hline $\begin{array}{l}\text { Direct Vs } \\
\text { Indirect } \\
\text { Admission }\end{array}$ & $\begin{array}{c}\text { First Aid / Pouring } \\
\text { Water }\end{array}$ & $\begin{array}{c}\text { Type of First Aid if Any } \\
\text { Used }\end{array}$ & \multicolumn{2}{|c|}{ Location of Accident } \\
\hline \multirow[b]{4}{*}{$63 \%: 37 \%$} & \multirow{4}{*}{$\begin{array}{l}\text { Only } 22 \% \text { confirmed } \\
\text { that they poured } \\
\text { water as first response } \\
78 \% \text { said either they } \\
\text { panicked and did not } \\
\text { know what to do or } \\
\text { were afraid water will } \\
\text { cause blisters and } \\
\text { cause more harm }\end{array}$} & Water & \multirow{3}{*}{$\begin{array}{l}\text { Domestic } \\
90 \%\end{array}$} & Kitchen $80 \%$ \\
\hline & & $\begin{array}{l}\text { Sugar Water } \\
\text { Potato Water }\end{array}$ & & $\begin{array}{c}\text { Bedroom/bathroom } \\
\text { /hall } 15 \%\end{array}$ \\
\hline & & $\begin{array}{c}\text { Ink } \\
\text { Milk }\end{array}$ & & $\begin{array}{c}\text { Vicinity of home } \\
5 \%\end{array}$ \\
\hline & & $\begin{array}{c}\text { Cooking Oil } \\
\text { Mobil Oil } \\
\text { Tooth Paste } \\
\text { Burned Ash } \\
\text { Homeopathic Cream } \\
\text { Homemade Paste }\end{array}$ & $\begin{array}{c}\text { School/ others } \\
10 \%\end{array}$ & \\
\hline
\end{tabular}

quarters of the year. Since our demography and social setup is closely identical with that of India because of being neighbor countries 11,14 . We also observed that Scalds was the commonest cause followed by thermal flame/electric burns. We

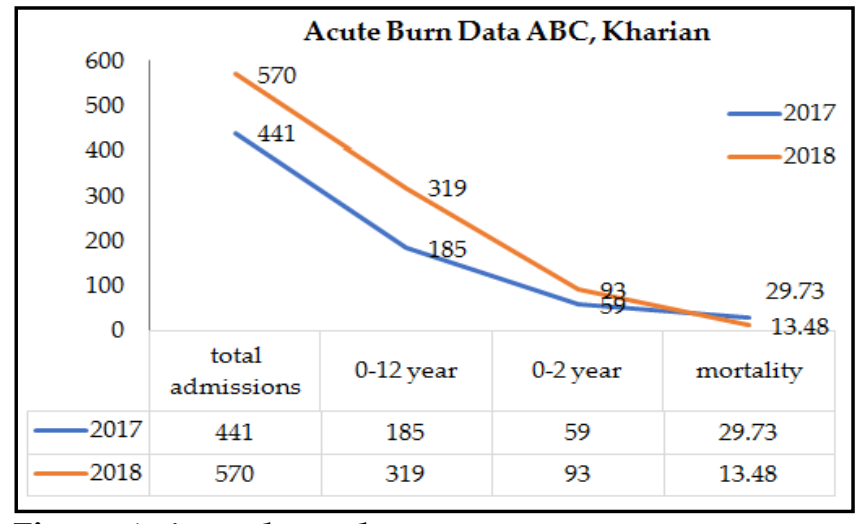

Figure-1: Acute burn data.

have also seen two peaks in pediatric burn admissions in Dec to Jan and Jun to Jul. It is peculiar with pediatric burns that there are more instances of pediatric burns in hot summer months ${ }^{14}$.

Zvizdic et $a^{3}$ in 2017 during a large study revealed that $84.9 \%$ burns were scalds, $97.3 \%$ burns occurred in the homes and the peak injury
There was $11.94 \%$ improved survival among these burn victims during the second half of the study. when we see it combined with a $72.43 \%$ increase in admissions in this period. This improvement translates into a large number of children healing and leaving the hospital ${ }^{3}$. This improvement in the final outcome is because we are following strict contact isolation protocols. All staff is regularly monitored and trained in hand hygiene and barrier nursing techniques. Enhanced environmental cleaning is being ensured by strictly following the protocols of our department. Judicious use of appropriate antibiotics along with early excision and graft for deep burns are some of the steps which have improved our clinical practice and the final outcome for our patients ${ }^{15-17}$.

Our study has clearly shown $72.43 \%$ more acute pediatric burn admissions. There were $29.25 \%$ overall more admissions during second half of the study. This significant rise in pediatric burn incidents between first and second half of study period may have a number of explanations. First and the foremost is that, there is no dedicated pediatric burn care facility in the whole of 
the country. We get a large number of referred/ transferred pediatric burn cases from other hospitals. Secondly probably there were more burn accidents in recent past in our catchment area. This study has proven beyond doubt that we have seen a significant increase in childhood burns but has failed to identify the exact cause of increased pediatric burns during second half of the study. This needs further evaluation and community research to identify the exact cause.

Bakker et al in clinical psychology review in $2013^{9}$ showed that child anxiety, traumatic stress reactions, and behavioral problems were considerably prevalent in the first months after the burn event. Among parents, high rates of posttraumatic stress, depressive symptoms, and guilt feelings were found ${ }^{10}$. It was our observation that the feeling of guilt and profound stress and agitation was commonly seen in the mothers of the burnt children ${ }^{18}$.

Prevention strategies should address the hazards for specific burn injuries, education for vulnerable populations and training of communities in first aid ${ }^{19,20}$. An effective burn prevention plan should be multisectoral and include broad efforts to improve awareness, develop and enforce effective policy, describe burden and identify risk factors, set research priorities with promotion of promising interventions, provide burn prevention programs, strengthen burn care, strengthen capacities to carry out all of the above $20-22$.

In 2009, Cuttle et al ${ }^{1}$ reported that more than $20 \mathrm{~min}$ of cold-water treatment following burn injury could significantly decrease hospitalization duration. In our study only $22 \%$ of the patients received this treatment. Therefore, improvement of first-aid education for parents/guardians may significantly improve burn prognosis in this population. We also need to make the use of flameretardant clothing and the use of smoke detectors mandatory ${ }^{23}$.

Burn treatment is very costly. It has a huge negative impact on healthcare system of any nation where government provides free treatment. In majority of developing countries like ours, no proper health insurance system exists. The public sector hospitals are inadequate and overcrowded, unable to cope up with the needs. Private treatment is very expensive and it has crushing impact on the financial standing of the victim's family. This huge negative financial impact on the economy of the country is enough justification to invest more aggressively in the country wide burn prevention campaign ${ }^{24,25}$.

\section{CONCLUSION}

We need to start a very aggressive campaign on print and electronic media for these preventable injuries and deaths. We probably need nationwide drive to educate our rural population to raise their stoves from ground, ban or restrict toddlers and children's entry into kitchens. We need to sensitize the population about this ghastly rising trend.

\section{CONFLICT OF INTEREST}

This study has no conflict of interest to be declared by any author.

\section{REFERENCES}

1. Cuttle L, Kravchuk O, Wallis B, Kimble RM. An audit of first-aid treatment of pediatric burns patients and their clinical outcome. J Burn Care Res 2009; 30(6): 1028-34.

2. Saeman MR, Hodgman EI, Burris A, Wolf SE, Arnoldo BD, Kowalske $\mathrm{KJ}$, et al. Epidemiology and outcomes of pediatric burns over 35 years at Parkland Hospital. Burns 2016; 42(1): 202-08.

3. Zvizdic Z, Bećirović K, Salihagić S, Milisic E, Jonuzi A, Karamustafic A. Epidemiology and clinical pattern of paediatric burns requiring hospitalization in sarajevo canton, bosnia and herzegovina, 2012-2016. Ann Burns Fire Disasters 2017; 30(4): 250.

4. Hashemi SS, Sharhani A, Lotfi B, Ahmadi-Juibari T, Shaahmadi $\mathrm{Z}$, Aghaei A. A systematic review on the epidemiology of pediatric burn in Iran. J Burn Care Res 2017; 38(6): e944-51.

5. Li H, Wang S, Tan J, Zhou J, Wu J, Luo G. Epidemiology of pediatric burns in southwest China from 2011 to 2015. Burns 2017; 43(6): 1306-17.

6. Saaiq M. Epidemiology and outcome of childhood electrical burn injuries at pakistan institute of medical sciences islamabad, Pakistan. J Burn Care Res 2016; 37(2): e174-80.

7. Iqbal T, Saaiq M. The burnt child: an epidemiological profile and outcome. J Coll Physicians Surg Pak 2011; 21(11): 691-94.

8. Dhopte A, Tiwari VK, Patel P, Bamal R. Epidemiology of pediatric burns and future prevention strategies - a study of 475 patients from a high-volume burn center in North India. Burns Trauma 2017; 5(1): 1-8.

9. Bakker A, Maertens KJ, Van Son MJ, Van Loey NE. Psychological consequences of pediatric burns from a child and family perspective: a review of the empirical literature. Clin Psychol Rev 2013; 33(3): 361-71. 
10. Parrish C, Shields A, Morris A, George A, Reynolds E, Borden L, et al. Parent distress following pediatric burn injuries. J Burn Care Res 2019; 40(1): 79-84.

11. Keshavarz M, Javanmardi F, Mohammdi AA. A decade epidemiological study of pediatric burns in south west of Iran. World J Plast Surg 2020; 9(1): 67.

12. Wang S, Li D, Shen C, Chai J, Zhu H, Lin Y, et al. Epidemiology of burns in pediatric patients of Beijing City. BMC paediatrics 2016; 16(1): 166.

13. Forjuoh SN. Burns in low-and middle-income countries: a review of available literature on descriptive epidemiology, risk factors, treatment, and prevention. Burns 2006; 32(5): 529-37.

14. Lal ST, Bhatti DJ. Burn injury in infants and toddlers: risk factors, circumstances, and prevention. Ind J Burns 2017; 25(1): 72.

15. James LE, Fowler LA, Warner P. 295 Predictors of Pediatric Burn Mortality from Admission Variables. J Burn Care Res 2019; 40(Suppl-1): S125-29.

16. Smolle C, Cambiaso-Daniel J, Forbes AA, Wurzer P, Hundeshagen G, Branski LK, et al. Recent trends in burn epidemiology worldwide: A systematic review. Burns 2017; 43(2): 249-57.

17. Xu Q, Xiao L, Zeng L, Dai Z, Wu Y. Pediatric burns in south central china: an epidemiological study. Int J Clin Exp Med 2018; 11(9): 9280-87.

18. Landolt MA, Grubenmann S, Meuli M. Family impact greatest: predictors of quality of life and psychological adjustment in pediatric burn survivors. J Trauma Acute Care Surg 2002; 53(6): 1146-51.

19. Bailey ME, Sagiraju HK, Mashreky SR, Alamgir H. Epidemiology and outcomes of burn injuries at a tertiary burn care center in Bangladesh. Burns 2019; 45(4): 957-63.

20. Arifi HM, Duci SB, Buja ZA, Zatriqi VK, Ramadani HI, Arifi $\mathrm{NH}$, et al. Epidemiology of pediatric burn injuries in Kosovo. Eur J Plast Surg 2017; 40(2): 123-26.

21. Xin W, Yin Z, Qin Z, Jian L. Characteristics of 1494 pediatric burn patients in Shanghai. Burns 2006; 32(5): 613-18.

22. Avci V, Kocak OF. Treatment algorithm in 960 pediatric burn cases: A review of etiology and epidemiology. Pak j Med Sci 2018; 34(5): 1185.

23. Moehrlen T, Szucs T, Landolt MA, Meuli M, Schiestl C. Trauma mechanisms and injury patterns in pediatric burn patients. Burns 2018; 44(2): 326-34.

24. Toon MH, Maybauer DM, Arceneaux LL, Fraser JF, Meyer W, Runge A. Children with burn injuries-assessment of trauma, neglect, violence and abuse. J Inj Violence Res 2011; 3(2): 98-106.

25. Hodgman EI, Saeman MR, Subramanian M, Wolf SE. The effect of burn center volume on mortality in a pediatric population: an analysis of the National Burn Repository. J Burn Care Res 2016; 37(1): 32-37. 